\title{
Łukasz Gałczyński
}

Uniwersytet Łódzki

\section{Wybory jako element demokratyzacji na obszarze byłego Związku Radzieckiego, na przykładzie Republiki Azerbejdżanu.}

\author{
„Azerowie są gotowi zagłosować na opozycję, \\ kiedy tylko dojdzie ona już do władzy"
}

Rozpad Zwiazku Radzieckiego spowodował drastyczne i nieodwracalne zmiany na arenie geopolitycznej. W jego wyniku powstało kilka państw nowych, a kolejne odrodziły się po dziesiątkach lat politycznego niebytu. Wśród państw tych znajdowały się m.in. państwa słowiańskie, bałtyckie oraz turkijskie - tak różnorodna mozaika etniczna, determinowała również znaczne różnice w poziomie rozwoju kultury politycznej, w różnych regionach ZSRR. Bardzo szybko rozpoczęto proces tranzycji systemowej, mający na celu jak najszybsze dostosowanie nowopowstałych państw, do dynamicznie zmieniającej się sytuacji międzynarodowej. Już na początkowym etapie, pojawił się szereg watpliwości, bowiem zaistniały liczne ośrodki (zarówno wewnętrzne i zewnętrzne), które odmiennie widziały przyszłość swoich państw. Pojawił się zatem dylemat: kto i w jakim stopniu powinien determinować zmiany, kto powinien być punktem odniesienia (Moskwa, Waszyngton, Bruksela, a może któryś z pomniejszych ośrodków jak Teheran), oraz najważniejsze pytanie jaki kierunek powinny przyjąć zmiany?1.

Perspektywa amerykańska oraz europejska wydawały się naturalnymi w kontekście upadku Związku Radzieckiego. Taką też postawę przyjęli ówcześni polityczni decydenci w Brukseli i Waszyngtonie. Podjęto działania na rzecz promo-

1 К. Столяров, Распад из Нагорного Карабаха в Беловежской пущи, Москва 2001. 


\section{6 tukasz Gałczyński}

wania demokracji liberalnej w rozumieniu zachodnim (okcydentalnym)². Próbowano dokonać implementacji standardów zachodnich do rzeczywistości dalece odbiegającej od sytuacji społeczno-politycznej w jakich te standardy tworzono. Decydenci europejscy i amerykańscy pomimo wielu lat zimnej wojny i ponad dwudziestu lat od upadku Zwiazku Radzieckiego, wciąż próbują dokonać na niemal każdej płaszczyźnie modyfikacji obowiązujących norm, na wzór europejski, nie dopuszczając myśli, że lokalne tradycje i wartości niekoniecznie przystają do wielu rozwiązań zastosowanych w wysoko rozwiniętych społeczeństwach, o wielowiekowej tradycji demokracji. Europocentryzm, jaki zapanował na fali euforii po zakończenie zimnej wojny, uniemożliwił sprawne korygowanie przyjętej linii politycznej tak, by lepiej sprawdzała się w dynamicznie zmieniającej się sytuacji.

Szczególnym przykładem takiego zachowania, mającego na celu upodobnienie systemu politycznego nowego państwa do wzorców zachodnich, były państwa turkijskie, takie jak potężny Kazachstan, biedny Kirgistan, czy leżący w najbardziej newralgicznym miejscu na arenie geopolitycznej, Azerbejdżan. Ich specyficzny charakter wynika z kilku elementarnych czynników, wśród których najważniejsze to: etnos turkijski ${ }^{3}$, religia islamska4 ${ }^{4}$, odległa historycznie (lub brak jakiejkolwiek) tradycja niepodległościowa 5 oraz specyficzny, klanowy charakter społeczeństwa ${ }^{6}$. Najciekawszy przypadkiem, dla studiów podjętych w pracy, wydaje się być Azerbejdżan - zewzględu na fakt, że na wyżej wymienione warunki nałożyła się wojna o Górski Karabach, która spotęgowała problemy społeczne i jeszcze wydatniej pokazała wartości jakimi kierowano się w życiu codziennym i politycznym.

Najbardziej czytelnym elementem postępów w procesie transformacji i demokratyzacji, w myśl zasady Schumpetera, jest charakter wyborów. Demokracja, którą usilnie próbowano zaszczepić na gruncie Azji Centralnej i Kaukazu Południowego, „to takie rozwiązanie instytucjonalne dochodzenia do decyzji politycznych, w którym jednostki uzyskują moc decydowania poprzez walkę konkurencyjną

2 J. Nichol, Armenia, Azerbaijan, and Georgia: Political Developments and Implications for U.S. Interests, Washington 2014, s.35-37.

${ }^{3}$ A. Smith, Etniczne źródła narodów, Warszawa 2009.

4 N. Konarzewska, Rola islamu w życiu politycznym Azerbejdżanu, www.kaukaz.pl/ pdf/rola_islamu_w_zyciu_politycznym_azerbejdzanu.pdf, data dostępu 22.02.2014.

${ }^{5}$ B. Baranowski, K. Baranowski, Historia Azerbejdżanu, Warszawa 1987, s.212-220.

6 O. Geukjian, Ethnicity, Nationalism and conflicts in the South Caucasus. Nagorno-Karabakh and the Legacy of Soviet Nationalities Policy, Ashgate 2012. 
o głosy wyborców"7. Dlatego też charakter forma i przebieg wyborów idealnie obrazują poziom demokratyzacji i postęp tranzycji w państwie.

Azerbejdżan do procesu transformacji przystępował w niezwykle trudnych warunkach wewnętrznych i zewnętrznych oraz przy znacznej fragmentaryzacji rodzimej sceny politycznej.

Sytuacja wewnętrzna w Azerbejdżanie była niezwykle skomplikowana. Gospodarka, w wyniku błędnego zarządzania w Związku Radzieckim, drastyczne ucierpiała - znikome wydobycie ropy nie przynosiło dochodów, do których miało potencjał; zdewastowane rolnictwo w początkowym etapie nie gwarantowało nawet bezpieczeństwa żywnościowego; brak przemysłu ciężkiego oraz słabo rozwinięty przemysł lekki powodowały, że Azerbejdżan nie posiadał produktów eksportowych, ani nawet nie był w stanie zaspokoić własnych potrzeb w wielu dziedzinach. Kryzys obejmował zatem strukturę produkcji, metody zarządzania, technologie produkcyjne oraz kapitał inwestycyjny. Wraz z upływem czasu, sytuacja pogarszała się, ze względu na wahanie Azerbejdżanu w sprawie wstapienia do WNP (która była głównym partnerem handlowym), przeciaganie się konfliktu o Karabach (co tragicznie drenowało budżet państwa), ogromna rzesza uchodźców (nie mających zamieszkania ani pracy) ${ }^{8}$, wymiana waluty (która obniżyła poziom rezerw złota) oraz niezrównoważona akcja prywatyzacyjna (mająca początkowo charakter korupcjogenny, a następnie niemal całkowicie wstrzymana). Azerbejdżan, który uchodził za oazę dostatku w Związku Radzieckim, w wyniku tranzycji (ale i wcześniejszych błędów), a przede wszystkim, w wyniku wojny, stał się synonimem biedy i niedostatku9. Stale pogarszająca się sytuacja ekonomiczna większości społeczeństwa oraz tragiczne warunki bytowe uchodźców wojennych, powodowały, że bardzo popularne stały się hasła dobrobytu i stabilizacji. Podczas gdy na wcześniejszym etapie, kwestie stricte polityczne odgrywały istotną rolę, z czasem zaczęły one być marginalizowane przez kwestie ekonomiczne.

Podstawowym elementem, jaki sprawiał, że objęcie władzy w Azerbejdżanie było procesem niezwykle złożonym, było znaczne zróżnicowanie etniczne państwa. Pomimo iż mniejszości etniczne i narodowe nie miały roli dominującej wobec

\footnotetext{
7 J. Schumpeter, Capitalism, socialism, democracy, London/New York 1994, s.375-408.

8 Azerbaijan State Commission On Prisoners of War, Hostages and Missing Persons, www.human.gov.azl, data dostępu 22.02.2014.

9 T. Świętochowski, Azerbejdżan, Warszawa 2006, s.149-156.
} 


\section{8 tukasz Gałczyński}

Azerów ${ }^{10}$, to ich pozycja była ugruntowana ze względu na fakt zamieszkiwania w zwartych grupach na trudno dostępnych terenach. Lezgini i Tałysze budzili się w swojej świadomości narodowej, ze względu na czynniki polityczne, a ich etniczność należy postrzegać w ujęciu instrumentalistycznym ${ }^{11}$. Zdecydowanie bardziej złożona była sytuacja w Górskim Karabachu, gdzie grupę dominującą stanowili Ormianie, mający silne wsparcie rządu w Erewaniu i diaspory. To właśnie irredentyzm Ormian karabachskich legł u podstaw wojny, która miała bezpośredni wpływ na kształtowanie się systemu politycznego w Azerbejdżanie ${ }^{12}$.

Sytuacja na froncie wybitnie determinowała procedury wyborcze oraz przebieg samych wyborów. Społeczeństwo Azerbejdżanu łatwo ulegało hasłom populistycznym, oferującym łatwe i szybkie zwycięstwo w wojnie, która w Azerbejdżanie traktowano bardzo emocjonalnie. Społeczeństwo liczyło na szybkie zdobycie potęgi militarnej i politycznej na skutek efektownego zwycięstwa wojnie. Jednocześnie wraz ze zmniejszającymi się regularnie szansami na jakikolwiek powodzenie operacji militarnej, narastała frustracja społeczna, na fali której, potęgowały się również pozostałe problemy kraju - ekonomiczne i polityczne. Drugim efektem wojny, jaki miał wpływ na przebieg wyborów, to skrajne uczucie upokorzenia i biedy, które spowodowało pragnienie jak najszybszej stabilizacji sytuacji i podniesienia warunków bytowych. W początkowej fazie zatem dominującymi była hasła szybkiego zwycięstwa, a w drugim etapie wojny mieszały się obietnice jak najszybszego zakończenia konfliktu (wciąż sugerowano zwycięstwo, jednak nie akcentowana go zbyt intensywnie) i ustabilizowania sytuacji wewnętrznej.

Bardzo ważnym elementem była również wewnętrzna scena polityczna Azerbejdżanu, którą można podzielić na kilka dominujących nurtów. Pierwszy, najważniejszym, była grupa działaczy komunistycznych związanych z Partią Komunistyczną Związu Radzieckiego, przemianowano na Partię Komunistyczną Azerbejdżanu, związani z pierwszym prezydentem, Jazem Mutalibowem³. Grupa ta, dominująca w republice związkowej od późnych lat osiemdziesiątych, zmonopolizowała struktury władzy, przejmując wszystkie najważniejsze stanowiska oraz użytkując dostęp do głównych środków produkcji. Druga grupa, w ramach tego

\footnotetext{
10 Statistical Yearbook of Azerbaijan 2006, State Statistical Committee, Baku, s. 69.

11 K. Czubocha, Separatyzm etniczny w dobie praw człowieka - nowe wyzwanie dla państwa dla narodowego i społeczności międzynarodowej, Toruń 2012, s. 18-24.

12 P. Adamczewski, Górski Karabach w polityce niepodległego Azerbejdżanu, Warszawa 2012.

13 T. Świętochowski, op. cit., s.141-144.
} 
ośrodka władzy, byli zwolennicy Hajdara Alijewa który, w wyniku rozgrywek na Kremlu, przebywał na zesłaniu politycznym w rodzimym Nachiczewanu, będącym de iure regionem autonomicznym Azerbejdżanu, a de facto samodzielnym państwem pod kontrolą Alijewa i jego klanu14. Początkowo grupa dominującą byli zwolennicy prezydenta, z czasem jednak w wyniku rozgrywek wewnątrzpartyjnych i ogólnonarodowych, Mutalibow znalazł się na wygnaniu, Elczibej przejął kontrolę nad państwem, a Alijew ostatecznie przejałł władzę. Drugi ośrodek to Front Ludowy Azerbejdżanu (FLA) założony jako instytucja organizująca poparcie społeczne dla przemian gorbaczowowskich, która jednak w wyniku przyjęcia przez działaczy antykomunistycznych, zamieniła się w środek oporu przeciw władzy w Baku, co jednak znamienne, w Azerbejdżanie hasła FLA były bardzo zachowawcze - prezentowały reformistyczne, ale nieagresywne stanowisko wobec Moskwy ${ }^{15}$. Od samego początku ruch ten, ze względu na swój inteligencki charakter, miał problemy ze znalezieniem wspólnego języka, zarówno wewnątrz grupy, jak i zdobyciem szerszego poparcia w społeczeństwie. Efektem takiego stanu rzeczy, była znaczna fragmentacja wolnościowej części sceny politycznej i wykształcenie się kilku partii, w których dochodziło do nieustannych utarczek i rozgrywek personalnych. Niemniej, na fali niezadowolenia z rządów Mutalibowa, dochodzi do przejęcia władzy przez obóz skrajnie prawicowy, co jednak kończy się fatalnie dla głównych partii wywodzących się z Frontu Ludowego. Do dziś na scenie politycznej działa kilku prominentów, którzy swoimi korzeniami polityczni sięgają działalności przed upadkiem Związku Radzieckiego. Niekończące się podziały, zarówno w łonie jednego, jak drugiego ugrupowania, powodowały chaos informacyjny i ostateczną utraty (i tak małego) zaufania społeczeństwa do klasy rządzącej. Jednak niezwykle istotne, w kontekście wyborów to brak bezpośredniego przełożenia niezadowolenia na frekwencję wyborcza, która zawsze utrzymywała się na wysokim poziomie - jest to swoisty paradoks, którego źródeł można upatrywać w aspekcie kulturowym, jednak mimo to, brak w pełni rzetelnego wyjaśnienia dla tej kwestii16.

Niezwykle istotnym czynnikiem jest również religia dominująca Azerbejdżanu, która jest szyizm islamski17. Znaczenie tego faktu ma trojaki charakter. Po

\footnotetext{
14 Ibidem.

15 P. Kwiatkiewicz, Przemiany polityczne w Azerbejdżanie. Od republiki radzieckiej do współczesnego państwa, Toruń 2013, s.142-158.

16 T. Świętochowski, op. cit., s.141-144.

17 J. Rohoziński, Święci biczownicy i czerwoni chanowie. Przemiany religijności muzułmańskiej w radzieckim i poradzieckim Azerbejdżanie, Wrocław 2005.
} 
pierwsze determinuje specyficzny kształt społeczeństwa, w którym pozycja kobiet jest mocno ograniczona, a dominująca rolę w rodzinie, będącej podstawą społeczeństwa, posiada ojciec, jako najstarszy członek rodu - to w oczywisty sposób implikuje istnienie pewnych nierówności społecznych oraz szczególnej dla państw islamskich (a nie tolerowanego przez europejskie) pozaprawnej deprywacji pewnych grup społecznych - kobiet i młodzieży. Bezpośrednim efektem takiego podejścia do tego zagadnienia jest zwyczaj głosowania w wyborach przez ojców rodziny, w imieniu wszystkich członków ${ }^{18}$. Zwyczaj ten naruszający jedną z najbardziej elementarnych zasad demokracji liberalnej, nie budzi jednak zastrzeżeń w samym Azerbejdżanie. Nierówność materialna uprawnień, dywersyfikowana w zależności od płci i wieku, determinuje również hierarchiczny charakter społeczeństwa i akceptację dla tak zwanych rządów silnej ręki, które postrzegane sa jako zagrożenie dla demokracji w rozumieniu europejskim, ale na wschodzie, są w pełni kompatybilne z zasadami reżimu ${ }^{19}$. Ostatni aspekt czynnika religijnego to, nie mający bezpośredniego wpływu na procesy wyborcze, wpływ Teheranu na scenę polityczną Azerbejdżanu. To sąsiednie mocarstwo regionalne, od samego początku miało ambicje, by odzyskać dominująca pozycję w regionie, jaką posiadało przez setki lat historii. Czynnik religijny, ze względu na rewolucję islamską w latach siedemdziesiąych, w Iranie, wydawał się być jednym z dominujących środków wpływu na Azerbejdżan i kreowanie postaw społecznych w tym państwie20.

Kolejna kwestia jaką należy rozpatrywać w kontekście transformacji systemowej w Azerbejdżanie, to bez watpienia wpływ etnosu turkijskiego. Azerowie określani nierzadko jako Turcy azerbejdżańscy, należą do tej samej rodziny ludów co Turcy, Kazachowie czy Uzbecy. Etnos turkijski jest niezwykle silnym, ponieważ kształtował się przez wiele wieków na kanwie islamskiej, jednak w opozycji do żywiołu arabskiego. Wielowiekowa tradycja dominacji państwa osmańskiego, ułatwiała identyfikację Azerów z tradycjami turkijskimi. Etnos był w sposób nieodpowiedzialny i niezorganizowany, wielokrotnie podkreślany, a żywioł turecki był budzony już w czasach Związku Radzieckiego (kiedy to podnoszono idę zjednoczenia Azerbejdżan północnego i południowego'1). Po upadku ZSRR również manipulo-

\footnotetext{
${ }^{18}$ por. Raporty KBWE z wyborów prezydenckich w latach 1991,1992,1993 i później.

19 M. Sadowski, Religie monoteistyczne o prawie i państwie, [w:] M. Sadowski, P. Szymaniec (red.), Religia, a prawo i państwo, Wrocław 2011, s.26-27.

20 T. Świętochowski, Azerbejdżan i Rosja. Kolonializm, islam i narodowość w podzielonym kraju, Warszawa 1998, s. 217-232.

21 Ibidem.
} 
wano pochodzeniem etnicznym, jako argumentem jednoczącym społeczeństwo w wojnie przeciwko Ormianom. Szczególnie aktywny na tym polu był jeden z ministrów w rządzie FLA-Musawat, Iskander Chamidow - będący przywódcą uznawanej za terrorystyczną organizacji Szare Wilki22. Etnos determinował bliskie stosunki z Ankarą oraz jej potencjalny wpływ na kształtowanie się pozycji międzynarodowej Azerbejdżanu (Turcja jako członek NATO była zdecydowanie lepszym protektorem dla nowego państwa, niż izolowany Iran czy uznana za spadkobierczynię ZSRR, Rosja). W samym procesie wyborczym, jako element wpływów turkijskich, można dostrzec kilka elementów: przede wszystkim potrzebę dominacji jednej osoby (kultura turecka bowiem implikuje zasadę silnej ręki), deprecjonując (ze względów kulturowych) konsensualizm, który jest jedną z podstaw demokracji liberalnych. Najważniejszym jednak efektem rozbudzenia żywiołu tureckiego, jest odrestaurowanie klanowego charakteru władzy23. System ten, opierając się na tradycyjnych więziach społecznych, gwarantuje stabilność władzy, oraz umożliwia zdobycie szerszego poparcia społecznego w myśl zasady "jeśli polityk umie zadbać o własną rodzinę, to będzie potrafił również zadbać o całe społeczeństwo". Takie ujęcie klanowości jest absolutnie odrzucane przez Zachód i jest postrzegane jako nepotyzm.

Dwie wyżej omówione kwestie czyli irańskie wpływy, wynikające z religii oraz tureckie, wynikające z etnosu, powodują tak zwany kompleks dwóch narodów w jednym. Azerowie dążą bowiem do zachowania historycznej równowagi pomiędzy Persami, którzy dominowali politycznie w tym regionie przez zdecydowaną większość historii państwowości, a Turkami, którzy ze względu na pokrewieństwo etniczne i językowe (a obecnie również zbieżność alfabetu), a w efekcie również kulturowe wydają się być bliżsi przeciętnemu Azerowi. W tej układance politycznej i kulturowej nie można również zapomnieć o obecności znacznej liczby Azerów w Iranie, gdzie na północy stanowią zwartą grupę, wielokrotnie walczącą o swoje prawa24.

Ostatni ze znaczących aspektów, jaki wpłynął na kształtowanie się życia politycznego w Azerbejdżanie, to historia wcześniejszej państwowości. Azerbej-

22 Z. Brzeziński, S. Paige, Russia and the Commonwealth of Independent States, Washinton 1997, s. 616 .

23 A. Ziuta, Nie hidżab, nie demokracja. Azerbejdżańska recepta na państwo, „Arena. Sprawy Międzynarodowe", nr 6(8) listopad 2011.

${ }^{24}$ E. Souleimanov, K. Pikal, J. Kraus, The Rise of nationalism among Iranian Azerbaijanis: a step toward Iran's disintegration?, "Middle East Review of International Affairs, nr 1(17), styczeń-marzec 2013, s.71-91. 


\section{2 tukasz Gałczyński}

dżan, poza krótkim epizodem w latach 1918-1920, nie posiada tradycji niepodległościowych. Od niepamiętnych czasów Chanat Azerbejdżanu znajdował się w granicach Persji, Imperium Osmańskiego oraz carskiej Rosji. Ten krótki etap po pierwszej Wojnie Światowej, został zakończony najazdem bolszewickim i włączeniem Azerskiej Socjalistycznej Republiki Radzieckiej do Zwiazku Radzieckiego25. We współczesnej polityce tylko partie prawicowe odwoływał się do pierwszej niepodległości - przekaz ten jednak nie jest dostatecznie trwały w świadomości narodowej, dlatego też ma on raczej charakter argumentu pomocniczego dla legitymizacji pewnych poglądów politycznych, aniżeli istotnego elementu, nawiazującego do kontekstu historyczno-politycznego. Jednocześnie, przez cały okres Związku Radzieckiego, istniało swoiste poczucie dobrobytu, umocnione szczególnie w okresie po II wojnie światowej, kiedy to aktywnie działano na rzecz zjednoczenia Azerbejdżanu, pod auspicjami Kremla oraz w latach osiemdziesiatych, kiedy to wysokie stanowiska państwowe zajmował Aliljew26.

W efekcie wieloletniej dominacji radzieckiej, kultura polityczna ukształtowana przez tradycje silnych rządów scentralizowanych, wynikająca z etnosu i religii, została ostatecznie sprowadzona do kultu siły. Nieufność wobec wartości instytucji demokratycznych, potrzeba nieustannego szukania wroga zewnętrznego oraz całkowita centralizacja władzy, zaowocowała niedemokratycznym praktykami, stosowanym przez wszystkie kolejne rządy (w tym również niosący na sztandarach hasła demokracji rząd Elczibeja). Efektem wprowadzenia sowieckiej kultury politycznej, było całkowite niezrozumienie dla idei obywatelskiego nieposłuszeństwa, będące jedna z elementarnych kwestii demokracji liberalnych ${ }^{27}$. Zamiast subsydiaryzacji i społeczeństwa obywatelskiego, wprowadzono rządy twardej ręki i ograniczanie części praw politycznych. Również z tradycji sowieckiej wywodzi się metoda upublicznienia spraw wewnętrznych poprzez oficjalne piętnowanie bądź nagradzanie. Doskonale, w tym kontekście oddaje obraz „zasada psa i tygrysa” (która choć wywodzi się z innego kręgu kulturowego, wydatnie pokazuje schemat działania notabli komunistycznych), by obawiać się przełożonego i zawsze podkreślać władzę wobec podwładnego. Szczególnym przykładem kultury politycznej Azerbejdżanu, w kontekście procesów wyborczych, jest możliwość wolnej dyskusji, agitacji, szero-

25 B. Baranowski, K. Baranowski, op. cit., s. 212-220.

26 T. Świętochowski, op. cit., s.161-233.

${ }^{27}$ P. Kwiatkiewicz, Przemiany polityczne w Azerbejdżanie. Od republiki radzieckiej do współczesnego państwa, Toruń 2013, s.147. 
ka wolności słowa, w tym nawet krytykowania władzy, dopóki jednak jej pozycja jest wystarczająco silna, by negatywne komentarze nie odnosiły realnego skutku w społeczeństwie ${ }^{28}$. Kolejne wybory pokazuja, że gdy tylko władza czuła się dostatecznie silna, by wygrać wybory znaczną przewaga, dopuszczała możliwość krytyki, co było swoistym wentylem bezpieczeństwa, gdy jednak jej pozycja słabła natychmiast podejmowano próby cenzurowania prewencyjnego.

Rok 1990 to rok poważnych przemian wewnętrznych w Azerbejdżanie. Początek roku to tak zwany Czarny Styczeń (Qara Yanvar)29, związany z walką o władzę, pomiędzy partię komunistyczną a Frontem Ludowym Azerbejdżanu, zakończone pogromem Ormian, wprowadzeniem stanu wyjątkowego oraz pacyfikacja stolicy przez wojsko radzieckie (w niezwykle brutalny sposób). Na fali tych wydarzeń dochodzi do zmiany na szczycie i nowym i sekretarzem Komitetu Centralnego Komunistycznej Partii Azerbejdżanu zostaje Ajaz Mutalibow. Niedługi czas potem, w ramach reformy struktur administracyjnych Mutalibow zostaje wybrany prezydentem AzSRR. W tym czasie mają też miejsce wybory do Rady Najwyższej AzSRR oraz zmiana statusu Nachiczewanu, w ramach Azerbejdżanu ${ }^{30}$.

Początek roku 1991 to przede wszystkim marcowe referendum w sprawie zachowania Związku Radzieckiego, w którym zdecydowana większość obywateli Azerbejdżanu opowiedziała się za pozostaniem w Imperium. Decyzja ta jednak nie ma większego znaczenia, wobec rozgrywek pomiędzy opozycja, a komunistami, w ramach których dochodzi do ogłoszenia niepodległości Republiki Azerbejdżanu. 30 VIII Rada Najwyższa uchwala właściwy akt31.

Tabela 1. Wyniki referendum nad zachowaniem Azerbejdżanu w ZSRR.

\begin{tabular}{|l|c|c|}
\hline \multicolumn{1}{|c|}{ Głos } & Liczba głosów & Procent głosów \\
\hline Za & $3,735,398$ & 99,8 \\
\hline Przeciw & 9,068 & 0,2 \\
\hline Głosów nieważnych & 6,708 & - \\
\hline
\end{tabular}

Źródło: D. Nohlen, F. Grotz, C. Hartmann, Elections in Asia: a data handbook, Tom I, Oxford 2001, s. 357.

\footnotetext{
28 Ibidem, s.195-404.

29 Ibidem, s. 167.

30 History of NAR, www.nakhchivan.az/portal-en/tarix.htm, data dostępu 20.02.2014.

31 Declaration of Independence Azerbaijan, ,http://azerbaijan.az/portal/History/HistDocs/Documents/en/04.pdf, data dostępu 20.02.2014.
} 
Pierwsze wybory prezydenckie odbyły się w Azerbejdżanie 8 IX 1991. Rozpisano je odpowiednio wcześnie mając świadomość dokonujących się przemian. Nowo obrany prezydent potrzebował usilnie legitymizacji społecznej, nie tylko w związku z krótkim okresem urzędowania, ale również ze względu na fakt, że jego władza miała umocowanie prawne w starym systemie ${ }^{32}$.

Wybory te dobitnie pokazały wszystkie cechy charakterystyczne sceny politycznej Azerbejdżanu. Można tę kwestię rozpatrywać w kategoriach zachowania elit politycznych (z trzech obozów, w związu z wystapieniem Alijewa z partii, na skutek rozgrywek po puczu Janajewa33) i społeczeństwa. Pierwszy aspekt to przede wszystkim kwestia organizacji wyborów i uczestnictwa poszczególnych partii w konkurencji wyborczej. Wprowadzono szereg warunków, które determinowały kształt list wyborczych. Najważniejsze to cenzus wieku, który de facto eliminował Alijewa, jako osobą zbyt starą. Zniesiono natomiast ograniczenie, na mocy którego kandydatami mogli zostać jedynie deputowani do Rady Najwyższej, co wydatnie podniosło konkurencyjność wyborów34. Do wyborów przystapił zatem Mutalibow, czyli ówcześnie urzędujący prezydent oraz jako jedyny kontrkandydat, Zarduszt Alizade, przedstawiciel Azerskiej Partii Socjaldemokratycznej (która wykształciła się z FLA i reprezentowała socjaldemokrację w rozumienie europejskim). Alizade jednak, mając świadomość, że nie jest w stanie zdobyć szerszego poparcia zrezygnował tuż przed głosowaniem pozostawiając Mutalibowa jedynym kandydatem ${ }^{35}$.

Szczególnym elementem wyborów było również ich otwarte kontestowanie przez Alijewa, będącego wówczas przywódcą Nachiczewanu, i w efekcie zablokowanie procesów wyborczych na terenie Republiki Autonomicznej. Decyzja Alijewa wybory w tej enklawie nie odbyły się, a władza centralna w Baku nie była w stanie takiego stanu rzeczy efektywnie zmienić.

\footnotetext{
32 P. Kwiatkiewicz, op. cit., s. 195-208.

33 Hejdar Alirza oglu Alijew - przywódca narodu azerbejdżańskiego,. www.lib.aliyevheritage.org/pl/2169646.html, data dostępu 20.02.0214.

34 P. Kwiatkiewicz, op. cit., s. 195-208.

$35 \mathrm{Ibidem}$.
} 
Tabela 2. Wyniki wyborów prezydenckich w Azerbejdżanie (bez NRA) w 1991

\begin{tabular}{|l|c|c|}
\hline \multicolumn{1}{|c|}{ Kandydat } & Liczba głosów & Procent głosów \\
\hline Ajaz Mutalibow & $3,275,837$ & 98.5 \\
\hline Przeciwko & 48,866 & 1,8 \\
\hline Głosów nieważnych & 460 & - \\
\hline
\end{tabular}

Źródło: D. Nohlen, F. Grotz, C. Hartmann, Elections in Asia: a data handbook, Tom I, Oxford 2001, s. 357.

Ciekawym aspektem jest również frekwencja wyborcza, która wniosła 85,7\%. Taki poziom, wręcz niespotykany przy dobrowolność wyborów w Europie, był wynikiem słabym jak na standardy azerskie. Tłumaczono niską frekwencję kontemplowaniem wolności obywatelskiej i ostentacyjnym nieuczestniczeniem w wyborach, które pierwszy raz nie tylko teoretycznie, ale i faktycznie nie były obowiazkowe. Mutalibow zdobył 98,5\% głosów poparcia dla swojej prezydentury. Nieliczna grupa, która postanowiła wyrazić sprzeciw, ograniczyła się najczęściej do oddawania głosów nieważnych lub kart wyborczych opisanych komentarzami36.

Sytuacja taka, związana z całościową oceną wyborów, dobitnie pokazuje specyfikę życia politycznego Azerbejdżanu - dominujący elementem jaki można dostrzec jest bez watpienia sowiecka kultura polityczna, która doprowadziła do formalistycznego manipulowania prawem wyborczym, co doprowadziło do wyeliminowania części przeciwników. Co jednak istotne, szereg osób uprawnionych do kandydowania w ogóle nie podjęło takiej próby, będąc świadomymi własnej słabości i zachowania społeczeństwa. Niezwykle wyraziste było również pragnienie stabilizacji wobec kryzysu jaki panował w ZSRR ${ }^{37}$ oraz zawirowania na rodzimej scenie politycznej tuż przed oraz po odzyskaniu niepodległości. Społeczeństwo zachowało postawa sceptyczną wobec przemian co paradoksalnie zaowocowało wzrostem poparcia dla starej władzy (Mutalibow bowiem przed wystapieniem z ZSRR deklarował potrzebę reform oraz konieczność pozostania w strukturze związkowej argumentując to uzależnieniem Republiki od współpracy z innymi republikami radzieckimi38; po ogłoszenie niepodległości wyciszył nieco głosy wspominające te poglądy, co ugruntowało jego kapitał polityczny jednocześnie wpisujacc go w aktualny kontekst polityczny). Co charakterystyczne dla państw turkijskich, społeczeństwo doce-

\footnotetext{
${ }^{36}$ D. Nohlen, F. Grotz, C. Hartmann, Elections in Asia: A data handbook, Tom I, Oxford 2001, s.357.

${ }^{37}$ P. Kwiatkiewicz, op. cit., s.384.

38 Ibidem, s.219-220.
} 
niło również determinację z jaką komuniści dążyli do utrzymania władzy ${ }^{39}$, wierząc że z równie dużym zaangażowaniem będą rządzić państwem (w społeczeństwie europejskim taka postawa wydaje się absurdalna).

Wybory oceniał szereg obserwatorów zagranicznych, którzy stwierdzili względną poprawność głosowania, zarzucając jednak niewłaściwe praktyki przy rejestracji kandydatów oraz w dostępie do środków przekazu. Pierwszy raz aktywnie również podkreślano rolę, jaką pełnili ojcowie rodziny, którzy głosowali w imieniu wszystkich członków (dla europejczyków, niezależnie od kontekstu, było to odejście od elementarnych zasad głosowania). Ostateczny werdykt mówił, że wybory były demokratyczne, ale ze znacznymi uchybieniami ${ }^{40}$.

Jak oceniono po latach, ludzie w Azerbejdżanie pragnęli: "w sensie duchowym - przywrócenia narodowej tożsamości, praw obywatelskich i demokracji w stylu brytyjskim, w sensie materialnym - pensji w stylu amerykańskim i szwedzki systemu wsparcia społecznego"41.

Rozpoczyna się okres zaledwie półrocznych rządów Mutalibowa, jako demokratycznie wybranego prezydenta. Okres związany bezpośrednio z eskalacja konfliktu o Górski Karabach, który budził emocje całego społeczeństwa oraz determinuje politykę zagraniczną Azerbejdżanu, co istotne, ocena tego okresu nie jest w pełni jednoznaczna ze względu na rosnące poparcie partii prawicowych, które skutecznie bojkotowały szereg działań ośrodka prezydenckiego. Do najważniejszych wydarzeń tego okresu należy zaliczyć przyjęcie Baku do organizacji takich jak WNP, ONZ, OBWE42 oraz na arenie międzynarodowej, fiasko rozmów z Kremlem, w sprawie stabilizacji sytuacji na Kaukazie Południowym, spowodowane zaangażowaniem FLA. Sytuację wewnętrzną zdominowały działania wojskowe, takie jak ofensywa w październiku 1991 i styczniu 1992 oraz katastrofa śmigłowca wojskowego z licznymi notablami na pokładzie. Punktem kulminacyjnym jednak stała się masakra w Chodżały, które miała miejsce 25 i 26 II 199243.

\footnotetext{
39 Ibidem, s.290-221.

40 CSCE Report of the CSCE/UN joint electoral observation mission in Azerbaijan on Azerbaijan's 8 September 1991 presidential election, Baku 1991.

${ }^{41}$ H. Hadjy-Zadeh, Azerbaijani Independence Was "Birth of Freedom" , "IWPR Reports", 623 grudzień 2011.

42 P. Kwiatkiewicz, op. cit., s. 219-220.

43 Azerbaijan State Commission On Prisoners of War, Hostages and Missing Persons, www.human.gov.az/, data dostępu 22.02.2014.
} 
5 III ma miejsce wiec w Baku, zorganizowany przez FLA, który doprowadza do ustapienia Mutalibowa z funkcji prezydenta 7 II. Pełniącym obowiązki zostaje przewodniczący Milli Medżlisu (parlamentu) - Jakub Mamedow. Rozpisane zostają kolejne wybory - termin zostaje wyznaczony na czerwiec. Jednak nim dochodzi do głosowania, w maju ma miejsce kolejna masakra, utrata strategicznie ważnych punktów na froncie (między innymi Szuszy), która zakończyła się próbą powrotu byłego prezydenta. Powrót kończy się zajęciem zbrojnym pałacu prezydenckiego i siedziby parlamentu, a następnie ucieczką Mutalibowa do Moskwy. Jednocześnie jednak wybrany zostaje nowy przewodniczący parlamentu, który staje się tym samym pełniącym obowiązki prezydenta. Isa Qambar (Musawat) miał w krótkim czasie wzmocnić pozycję prawicy, która wobec totalnej postawy Mamedowa mocno ucierpiała (był on powszechnie obwiniany za utratę Szuszy, z czego do dziś się tłumaczy publicznie oraz zniknał w niejasnych okolicznościach, w trakcie powrotu Mutalibowa) ${ }^{44}$.

Kolejne wybory prezydenckie odbywają się zgodnie z planami 7 VI 1992. Startuje w nich pięciu kandydatów. Po raz kolejny nie może startować Alijew, ze względu na cenzus wieku, który pomimo demokratycznych haseł prawicy nie został zniesiony, ze względu na tego konkretnego polityka. Swojego kandydata nie wystawia również Partia Komunistyczna, która po obaleniu prezydenta została całkowicie rozbita wewnętrznie. Możliwości startowania nie uzyskał też Ettibar Mamedow, będący głównym oponentem wewnątrz partii FLA. Zarząd partii podjął decyzję wystawienia tylko jednego kandydata i tym samym Mamedow otrzymał zakaz startowania w wyborach. Warunkiem uzyskania wpisu na listę kandydatów było zebranie dwudziestu tysięcy podpisów45.

Kandydaci to: Abulfaz Elczibej (FLA), Nizami Sulejmanow (Unia Demokratyczna Inteligencji Azerbejdżanu), Jakub Mamedow (niezależny), Ilja Ismaiłow (Ruch na Rzecz Reform Demokratycznych), Rafik Abdułajew (Grupa NarodowoDemokratyczna). Wśród kandydatów dominowali zdecydowanie przedstawiciele prawej strony sceny politycznej. Wszyscy oni wywodzili się z ruchu antykomunistycznego i byli ściśle związani z rządem tymczasowym powołanym po odsunięciu Mutalibowa. Głównymi hasłami wyborczymi było zwycięstwo w Górskim Karabachu

44 P. Kwiatkiewicz, op. cit., s. 239-254.

45 The Presidential Election of 1992, www.countrystudies.us/Azerbaijan /30.htm., data dostępu 20.02.2014. 
oraz poprawa sytuacji gospodarczej, poprzez zabiegi socjalne, takie jak obniżka cen żywności i wsparcie dla najuboższych. Jak więc można ocenić, wybory miały charakter pluralistyczny, jednak wiedza dotycząca przygotowań do wyborów (szczególnie istotny jest tu wcześniejszy zamach stanu i siłowe rozwiazanie kwestii władzy) pokazuje dobitnie jakie czynniki naprawdę decydowały o legitymizacji władzy. Doskonale w tym wypadku sprawdza się hasło, że Azerowie zagłosują na opozycję kiedy dojdzie do władzy. Jest to doskonale zauważalny przejaw sowieckiej kultury politycznej, wsparty uwarunkowaniami etnicznymi i religijnymi, czyli potrzebą twardej ręki.

W kampanii przedwyborczej, która charakteryzowała się uczciwym i równym dostępem do środków przekazu pojawił się również ponownie aspekt możliwości krytyki i wolnej dyskusji, ale tylko w ramach zwycięstwa jednej partii - od samego początku bowiem nikt nie miał watpliwości że zwycięstwo należy do Elczibeja46.

Bezpośrednio w samym procesie oddawaniu głosów, zachodni obserwatorzy doszukali się szeregu uchybień, w tym najważniejszego - głosowania ojców rodziny za wszystkich jej członków. Pomimo tego stwierdzono, że wybory były demokratyczne, z nielicznymi uchybieniami - dokonał się znaczny postęp na drodze do demokratyzacji Azerbejdżanu47.

Elczibej zwyciężył zdobywając 60,9\% głosów, przed Sulejmanowem $(33,8 \%)$. Pozostali kandydaci nie przekroczyli dwóch procent poparcia. Takie zwycięstwo było z jednej strony oczywistym wynikiem, z drugiej jednak wysokie poparcie dla Sulejmanowa było ciekawym zjawiskiem. Tłumaczyć to można podobnym charakterem działalności politycznej co zwycięzca wyborów oraz niemalże identycznymi hasłami.

46 P. Kwiatkiewicz, op. cit., s. 239-254.

47 CSCE Report of the CSCE/UN joint electoral observation mission in Azerbaijan on Azerbaijan's 7 June 1992 presidential election, Baku 1992. 
Tabela 3. Wyniki wyborów prezydenckich w Azerbejdżanie

\begin{tabular}{|l|c|c|}
\hline \multicolumn{1}{|c|}{ Kandydat } & Liczba głosów & Procent głosów \\
\hline Abulfaz Elczibej & $1,829,448$ & 60,9 \\
\hline Nizami Sulejmanow & $1,017,217$ & 33,8 \\
\hline Jakub Mamedow & 51,144 & 1,7 \\
\hline llja Ismiałow & 20,216 & 0,7 \\
\hline Rafik Abdullajew & 15,646 & 0,5 \\
\hline
\end{tabular}

Źródło: D. Nohlen, F. Grotz, C. Hartmann, Elections in Asia: a data handbook, Tom I, Oxford 2001, s.357.

Rozpoczyna się kolejny etap historii Azerbejdżanu - oto bowiem pierwszy raz od czasów przed inwazją bolszewicką w wyborach do władzy dochodzą niekomuniści. Jednak od samego początku przyjmują oni praktyki dalece odbiegające od liberalno-demokratycznych haseł, jakie mieli wypisane na swoich sztandarach. Pierwszym podstawowym zabiegiem jaki zastosowano to masowa zmiana kadr według klucza klanowego i partyjnego. Jest to wybitny dowód na inne postrzeganie kwestii kadrowych aniżeli jest przyjęte na zachodzie. Nawet partie o tak silnie prawicowym zabarwieniu (a w tym wypadku proeuropejskim kierunku), bezpośrednio po dojściu do władzy dokonują oczyszczenia aparatu administracyjnego (co można tłumaczyć potrzebą sanacji państwa)48, dokonując następnie rekrutacji pomiędzy swoimi zwolennikami i klientami (co w warunkach europejskich jest absolutnie niedopuszczalne). Postawa taka wynika z radykalnych haseł antyrosyjskich nowego prezydenta, ale też całkowicie innego postrzegania państwa i polityki. Interakcje pomiędzy nimi, a zapleczem personalnym partii - dla Azerów nie jest to przejaw nepotyzmu, ale pozytywnie odbieranych determinacji w dążeniu do celu i troski o losy związanych z nimi ludzi. Niestety zmiana taka nie była możliwa ze względu na elementarne braki kadrowe, co w krótkim czasie doprowadziło do kuriozalnych sytuacji, w której na forum publicznym krytykowano poprzedni aparat, jednocześnie angażując ich w służbie nowej władzy. Przyniosło to opłakane skutki, w postaci drastycznie pogarszającej się sytuacji gospodarczej, nieregulowanej subsydiaryzacji władzy oraz chaosu decyzyjnego. Władza nie mając doświadczenia w wykony-

48 T. Świętochowski, Azerbejdżan, op. cit., s. 153. 
waniu tak złożonych zadań zareagowała próbą brutalnej centralizacji co jeszcze bardziej pogorszyło sytuacjęe ${ }^{49}$.

Coraz gorzej wyglądała też sytuacja gospodarcza wynikająca z całkowitego zahamowania prywatyzacji, nieumiejętnej reformy monetarnej (która drastycznie zmniejszyła rezerwy złota) oraz niewłaściwego zarządzania. Spadające od dłuższego czasu obroty handlowe z za granica niemal całkowicie wyhamowały spory z Kremlem, w ramach WNP i OUWB50.

Wraz z pogorszającą się sytuacją gospodarczą i polityczną w Baku pogarsza się sytuacja na froncie. Ormianie, po zajęciu kolejnych kluczowych punktów, zaatakowali AR Nachiczewanu, w której samodzielnie rządził Alijew. Ze względu jednak na poziom autonomii prowadził on samodzielną i skuteczną politykę fiskalna, energetyczną i militarna, co owocuje zwycięstwem militarnym i skutecznym odparciem ofensywy. Odpowiedzialność za atak ponieśli rządzący w Baku, jednak laur zwycięstwa otrzymał osobiście Alijew. Skuteczne zarządzanie, którego efektem było podniesienie poziomu życia w Republice Autonomicznej wraz z dobrymi stosunkami jakie zbudowano zarówno z Iranem jak i z Turcją (prezydent wspierał się jedynie na współpracy z Turcją traktując Iran jako rywala w walce o Azerbejdżan Południowy), spowodowały gwałtowny wzrost poparcia dla Alijewa. Prezydent zdając sobie sprawę z sytuacji, postanawia przywrócić kontrolę nad autonomia, pozbawiając potencjalnego rywala zaplecza politycznego. Próbę taką podjęto w październiku 1992 roku, jednak zakończyła się ona porażką militarną (oddziały OMON zostały odparte) i wizerunkowa prezydenta. Prawa strona sceny politycznej pokazała prawdziwe oblicze - zamiast haseł demokratyzacji doszło do próby siłowego rozwiązania niewygodnej dla władzy sytuacji51.

Chwilowe poszerzenie przestrzeni politycznej, wynikające z przejściowych sukcesów na froncie (co było efektem realizacji porozumień o podziale schedy militarnej po Związku Radzieckim w ramach którego Azerbejdżan uzyskał znaczne zapasy broni), zakończyło się wraz z ogromnymi stratami oraz zajęciem przez Ormian kluczowego Kelbadżaru. Spowodowało to próbę siłowego rozprawienia się z druga z postaci życia publicznego, która obok Alijewa zdobyła znaczna popularność - w VI 1993 odwołany z funkcji wojskowej zostaje Surat Husejnow. Świadomy swojego trudnego położenia politycznego (ogłoszono go winnym porażek militar-

\footnotetext{
49 Ibidem, s. 142-149.

50 Ibidem.

51 P. Kwiatkiewicz, op. cit., s.268-288.
} 
nych, pomimo iż jego wina była jedynie pośrednia) i trudnego położenia geograficznego jego oddziałów (w przeciwieństwie do Alijewa był on zagrożony bezpośrednim starciem militarnym z oddziałami wiernymi prezydentowi) podejmuje natychmiastową decyzję konfrontacji z urzędującym prezydentem - zajmuje drugie co do wielkości miasto Azerbejdżanu, rodzimą Gandżę, następnie stawia ultimatum polityczne Baku rozpoczynając jednocześnie powolny marsz na stolicę. Do gry włącza się Hajdar Alijew, dotychczas cierpliwie czekający na korzystniejszą sytuację do konfrontacji z władza, która stopniowo traciła legitymizację społeczną (wypływająca z haseł zarówno stricte politycznych, jak i kulturowo-ideowych, takich jak panturkizm i ponownie rozbudzone nadzieje na zjednoczenie z południowym Azerbejdżanem). Alijew podejmuje się roli pośrednika w rozmowach pomiędzy zbuntowanym pułkownikiem, a urzędujacym prezydentem - kolejne tury negocjacji zgodnie z oczekiwaniami nie przynoszą wymiernych efektów. Husejnow wkracza do stolicy zajmujący strategiczne punkty, Elczibej ucieka do rodzinnej wioski w Nachiczewanu (gdzie niejako na łasce Alijewa prowadzi działalność przeciwko nowym władzom), a Alijew zostaje doradca zbuntowanego dowódcy. Taki układ sił determinuje uprzywilejowaną rolę Alijewa, który jednocześnie staje się de facto przywódca, nie ponosząc przy tym szerszej odpowiedzialności politycznej52.

Krótko po zmianie warty w Baku dochodzi do zbrojnej próby zablokowania parlamentu przez zwolenników FLA, co jednak kończy się klęską. 15 VI 1993 Hajdar Alijew zostaje wybrany na przewodniczącego parlamentu, a tym samym pod nieobecność Elczibeja, pełniącym obowiązki prezydenta. Dzień ten jest obecnie świętowany jako Dzień Ocalenia Narodowego i jest oficjalnym świętem państwowym w Azerbejdżanie. 27 VI 1993 ostatecznie dochodzi do przypieczętowaniem zmiany władzy, poprzez porozumienie między Husejnowem (będący oficjalnie inicjatorem i główną postacią przewrotu), a Alijewem (będącym jedynie doradca, a jednocześnie głównym beneficjentem dokonujących się przemian) 53 .

Alijew w krótkim czasie podejmuje strukturalną reformę najważniejszych elementów państwa - skutecznie reguluje sytuację pozostałych mniejszości narodowych (Lezginów i Tałyszy), które na fali puczu wojskowego, próbują wybić się na niepodległość; rozpoczyna reformę armii oraz co istotne, z opóźnieniem dokonuje wymiany kadr (świadomy szkodliwości wizerunkowej gwałtownych zmian kadro-

\footnotetext{
52 Ibidem.

53 Ibidem, s. 289-312.
} 
wych dokonuje ich stopniowo, jednak skutecznie monopolizując proces decyzyjny, a później także struktury) ${ }^{54}$.

W VIII na miejsce referendum w sprawie odwołania Abulfaza Elczibeja z funkcji prezydenta. 98\% głosów za odwołaniem, przy frekwencji 91,6\%, dobitnie pokazuja poziom kultury politycznej w kraju, gdzie w ciagu niespełna roku można stracić niemal całkowicie poparcie społeczne. Co istotne, jeszcze na kilka dni przed upadkiem, prezydent cieszy się kilkudziesięcioprocentowym poparciem według sondaży, które jednak natychmiast utracił w wyniku puczu - społeczeństwo popierajace rządy twardej ręki kolejny raz opowiedziało się po stronie silniejszego. Wybitnie też wzrosło pragnienie stabilizacji, obiecywanej w kolejnych kampaniach wyborczych, która jednak na razie osiagnął tylko Alijew w RA Nachiczewanu.

Tabela 4. Referendum ws. zachowania prezydenta na stanowisku.

\begin{tabular}{|l|c|c|}
\hline \multicolumn{1}{|c|}{ Głos } & Liczba głosów & Procent głosów \\
\hline Tak & 77,730 & 2 \\
\hline Nie & $3,673,978$ & 98 \\
\hline
\end{tabular}

Źródło: D. Nohlen, F. Grotz, C. Hartmann, Elections in Asia: a data handbook, Tom I, Oxford 2001, s.357.

Kolejne wybory odbywają się 3 X 1993 (rozpisane zostają zaraz po przejęciu władzy - $15 \mathrm{VI} 1993)^{55}$. Wybory te powtarzają schemat po raz trzeci - od samego początku tworzono liczne trudności dla rejestracji kandydatów tak, że ostatecznie zarejestrowano czterech polityków, ale startuje w wyborach jedynie trzech. Sa te postacie zwiazane z środowiskiem Alijewa: Kerar Abilow (nacjonalistyczny komunista z Partii Wielkiego Azerbejdżanu) oraz Zakir Tagijew (oligarcha z branży budowlanej). Ostatnim z kandydatów był Isa Qambar, który jako jedyny polityk z obalonego reżimu uzyskał prawo kandydowania - jednak zrezygnował on przed głosowaniem, będąc świadomym znikomego poparcia jakie posiada ${ }^{56}$.

54 Ibidem, s. 315-331.

55 P. Kwiatkiewicz, op. cit., s.332-343.

56 Presidential election In Azerbaijan 1995, www. cia.gov/ library/publications/the-world-factbook, data dostępu 20.02.2014. 
Tabela 5. Wyniki wyborów prezydenckich w Azerbejdżanie.

\begin{tabular}{|l|c|c|}
\hline \multicolumn{1}{|c|}{ Kandydat } & Liczba głosów & Procent głosów \\
\hline Hajdar Alijew & $3,919,923$ & 98,84 \\
\hline Kerar Abilow & 40,298 & 1,05 \\
\hline Zakir Tagijew & 6,406 & 0,15 \\
\hline
\end{tabular}

Źródło: D. Nohlen, F. Grotz, C. Hartmann, Elections in Asia: a data handbook, Tom I, Oxford 2001, s.357.

Kolejny raz ukazały się wszystkie charakterystyczne cechy życia politycznego Azerbejdżanu - społeczeństwo opowiedziało się za politykiem, który już de facto posiadał władzę, wybierając jego hasła stabilizacji społecznej i politycznej kraju. Alijew jak nikt inny potrafił zdobywać szacunek społeczny wykorzystuje swój wiek doświadczenie oraz sukcesów przeszłości. Jednocześnie jak nikt inny potrafił on dokonać specyficznego mariażu dążeń panturkijskich (który tak aktywnie promował Elczibej), wizji zjednoczenia obu Azerbejdżanów (nieakcentowana jednak wprost) oraz zachowania dobrych relacji z bliskimi kulturowo Iranem (cieszył się przychylności Teheranu). Alijew jak nikt inny łączył kompleks dwóch narodów w jednym ${ }^{57}$.

W ocenie wyborów, uznanych po raz kolejny, przez zachodnich obserwatorów, za częściowo wolne z licznymi uchybieniami, nie uwzględniono kontekstu wcześniejszych przemian władzy w wyniku których prawa część sceny politycznej została niemal całkowicie wyłączona z życia publicznego. Uznano częściowy pluralizm polityczny, podkreślając liczne uchybienia w trakcie głosowania i liczenia głosów58.

Niekwestionowane zwycięstwo odniósł kandydat Partii Nowego Azerbejdżanu, zdobywając 98,84\%. Pozostali kandydaci zyskali kolejno 1,01\% i 0,15\% głosów.

Okres rządów Alijewa charakteryzuje przypieczętowanie tradycji i wartości tak nie zrozumiałych dla europejskich decydentów - wymiana kadr według klucza partyjnego i klanowego59, ostateczne usunięcie od władzy i z życia publicznego

57 T. Świętochowski, Azerbejdżan i Rosja. Kolonializm, islam i narodowość w podzielonym kraju, Warszawa 1998, s. 262.

58 CSCE Report of the CSCE/UN joint electoral observation mission in Azerbaijan on Azerbaijan's 8 September 1991 presidential election, Baku 1993.

59 W Azerbejdżanie istnieje anegdota: mężczyzna, który właśnie przybył do Baku wsiada do taksówki. 
przywódców resortów siłowych - Husejnowa i Dżawadowa (zasada psa i tygrysa60) w sposób niezwykle widowiskowy poprzez publiczne potępienie na mityngu politycznym. Wreszcie powołanie pod przewodnictwem Alijewa specjalnej komisji mającej zająć się formułowaniem nowej konstytucji.

Wszystko to poparte sukcesami reformatorskim - wprowadzeniem Azerbejdżanu do WNP, podpisaniem traktatu w Biszkeku (kończącego wojnę o Karabach), podpisaniem kontraktu stulecia (który znacznie podniósł poziom dochodów państwa), wznowieniem akcji prywatyzacyjnej oraz ustabilizowaniem życia społecznego 61.

Wybory parlamentarne 1995 wraz z uzupełniającymi na początku 1996 potwierdziły dominującą rolę partii Alijewa w życiu publicznym62. Pomimo protestów opozycji, opinia OBWE była pozytywna, frekwencja wysoka $(86,5 \%)$, a do startu dopuszczono aż 8 partii oraz blisko czterystu kandydatów, którzy w mieszanym systemie wyborczym dokonali głosowania. Wykazywano liczne uchybienia, takie jak zaangażowanie policji, wielokrotne głosowanie, błędy w liczeniu głosów czy głosowanie przez ojców rodziny. Jednocześnie jednak podkreślano niezwykle pluralistyczny charakter debaty przedwyborczej63, do której dopuszczono w szerokim zakresie wszystkich kandydatów, niezależnie od ich poglądów a także umożliwiono krytykę rządzących - zgodnie z oczekiwaniami prezydenta nie odniosło to skutecznego efektu, bowiem społeczeństwo, znudzone kłótniami, ponownie poparło najsilniejszego gracza, zgodnie głosując na partię prezydencką (59 ze 125 miejsc w parlamencie i $62 \%$ poparcia w głosowaniu proporcjonalnym).

W 1998 miały miejsce kolejne wybory prezydenckie64, w ramach których ponownie podkreślano błędy przy organizacji wyborów, jednocześnie podkreślając demokratyczny charakter. Szczególnym aspektem była debata przedwyborcza, w której nie obowiązywała cenzura (co jest ewenementem na skalę całej WNP). Co istotne pomimo częściowego ograniczenia korzyści rejestracji kandydatów w wyborach wystartowali między innymi Mamedow i Sulejmanow, związani z poprzednim

\footnotetext{
- Dokąd? - pyta taksówkarz

- Na stanowisko - odpowiada przyjezdny.

60 P. Kwiatkiewicz, op. cit., s.383.

61 Ibidem, s. 365-385.

62 OSCE Report of the OSCE/UN joint electoral observation mission in Azerbaijan on Azerbaijan's parliamentary election, Baku 1996.

63 P. Kwiatkiewicz, op. cit., s. 401.

64 OSCE Report of the OSCE/UN joint electoral observation mission in Azerbaijan on Azerbaijan's presidential election, Baku 1998.
} 
reżimem, a urzędujący prezydent zdobył $77.6 \%$ głosów (co jest wiarygodnym wynikiem w kontekście ówczesnych nastrojów społecznych).

Azerbejdżan w wyniku zmieniającej się sytuacji politycznej, od samego początku znalazł się w szarej strefie transformacji, a jego reżim przyjmował kolejne formy hybrydalne. W początkowej fazie był to rywalizacyjny autorytaryzm, w którym dominująca postacią był Ajaz Mutalibow. Odsunięcie go od władzy doprowadziło do nieudanej próby wprowadzenia demokracji, zakończonej ostatecznie fazą tak zwanej nieliberalnej demokracji, w której władza wybrana w wyborach uznanych za wolne narusza elementarne prawa - swobodę wypowiedzi swobody polityczne oraz zasadę trójpodziału władzy. Okres rządów Abulfaza Elczibeja, który niósł ze sobą największe nadzieje zakończył się jednocześnie jego spektakularną klęską zarówno polityczna, jak i wizerunkową. Na fali tej porażki, Azerbejdżan przeszedł do fazy demokracji delegacyjnej, w której Hajdar Alijew, w wyborach uznany za częściowo wolne, przejmuje formalnie władzę by realizując misję zbawienia ojczyzny bez konsekwencji naruszać normy konstytucyjne oraz obowiązujące prawo. Opanowanie sytuacji wewnętrznej w sytuacji kryzysowej, prowadzi do konsolidacji reżimu i ostatecznie zastosowania hybrydy obowiazującej do dziś, jaką jest reżim siły dominujacej, w którym grupa polityków i klientów zgromadzonych wokół prezydenta całkowicie monopolizuje aparat państwowy. Azerbejdżan to jedno z nielicznych państw, które w tak krótkim czasie znalazło zastosowanie dla tak licznych form hybrydalnych oraz zmieniających się warunków ich ewolucji.

Azerbejdżan to państwo całkowicie odmienne od zachodnioeuropejskich społeczeństw. Wynika to z wielu czynników - kultury sowieckiej (która jest elementem rywalizacji, możliwym ze względów politycznych, do wyeliminowania), ale też etnosu turkijskiego i religii islamskiej (determinowanej przez ośrodki w autorytarnym Iranie). Społeczeństwo Azerbejdżanu kieruje się innymi wartościami i tradycjami w życiu politycznym aniżeli Europejczycy. Okcydent nie jest zdolny do zrozumienia tej odmienności i skutecznej współpracy z wytworzonymi w tych szczególnych warunkach ośrodkami. Polityka klanowa będąca dla Brukseli przejawem nepotyzmu, jest dowodem na umiejętności zadbania o własne zaplecze, a także o losy całego kraju; rządy twardej ręki będące dla Waszyngtonu przejawem autorytaryzmu są dla Azerów oczywistą koniecznością w panujących warunkach politycznych; uchybienia w głosowaniu będące dowodem na regresję demokracji, są uświęconą historycznie tradycją życia społecznego. Dopóki świat zachodni nie zrozumie, że wartości jakimi kieruje się społeczeństwo Azerbejdżanu są całkowicie inne, aniżeli 


\section{6 | Łukasz Gałczyński}

te istniejące w społeczeństwie zachodnim, tak długo budowanie wspólnych platform dla porozumienia politycznego będzie niezwykle trudne.

Wybory polityczne, będące dla świata zachodniego miernikiem demokratyzacji, najdobitniej pokazuja że Azerbejdżan może być państwem dobrobytu, opartym na zadowoleniu społecznym, bez metod działania i wartości promowanych przez Okcydent. 